\title{
Effect of Bio-Fertilizer and Calcium Nitrate on Vegetative and Flowering Growth of Tulipa Sp. CV. Orange Casing
}

\author{
Ban Abood ${ }^{1}$ \\ Department of Horticulture and gardening design, College of Agriculture, \\ University of Baghdad, Iraq
}

\begin{abstract}
This study was carried out in lath housel Horticulture and gardening design Department, College of Agriculture in 2015-2016 year, to study the effect of Azospirillumbrasilense and calcium nitrate in three levels ( 0 , 627, 1254) mg.L-1 on Tulipa sp. cv. orange cassing. Results showed the Azospirillumbrasilense treatment increased leaf dry weight, leaf area, and decreased the toppled stem percentage to 0,25g, $158.17 \mathrm{~cm} 2$ and $16.67 \%$ respectively. However used Cal increasing leaves dry weight, leaf area and flower stem height to $0.27 \mathrm{~g}$, $154.55 \mathrm{~cm} 2$ and $21.65 \mathrm{~cm}$ respectively as well as the $N, P, K$ percentage enhanced to $1.47,0.53$ and $1.55 \%$ respectively. Ca2 treatment recorded minimum days to sprouting (74.25 days), increased flowers number (1.33 flower) and vase life for flower stored at 40C to 3 day.
\end{abstract}

Keywords: Tulipabulbs,Azospirilliumbrasilense, Biofertilization.

\section{Introduction}

Tulip (Tulipasp.)can be considered as one of the most important annual winter bulbs belongs to Lilaceae family. NetherLands and France are the first producers of tulip. NetherLands alone exported about $70 \%$ of bulbs and cut flower yearly [1]. Scientific studies ensured the importance of bio-fertilizer to improve plant growth by increasing the availability of necessary elements such as nitrogen in rhizosphere zone [2].

Khan et al [3] found that dipping tulip bulbs (tulipa gesneriana L.)in three kinds of bio-fertilizers (control, Azospirillum lipoferum, Azotobacter chroococcum), with four doses of nitrogen $(0,50,75,100) \%$, improved plant height to $38.90 \mathrm{~cm}$, leaf area $143.39 \mathrm{~cm} 2$, bulbs yield and tepals diameter at the Azotobacter treatment then followed by Azospirillum treatment, as well as increasing $\mathrm{N}$ from 0 to $100 \%$ enhanced the bulbs properties and growth but the flowering delayed, the interaction effect was recommended Azotobacter $+100 \%$ of $\mathrm{N}$ it increased the growth, bulbs yield and flower quality. The present researches showed successful finding for vegetative and reproductive growth by bio-fertilizers application at Gladiolus grandiflorus L., however , the Azospirillum treatment increased plant height, spike length and florets.Spike-1 and sprouted early than other treatments (control, Rhizobium, Azotobacter and P solubilizing bacteria) as well as Azospirillum treatment enhanced the nutrient percentages $(\mathrm{N}, \mathrm{P}, \mathrm{K})$ than the control [4]. Adding bio-fertilizer (Azospirillium brasilense + Mycorrhizafungi) leaded to increase plant length, leaf area, the percentage of dry matter, (N,P.K) percentage and vase life after storage at $6 \pm 20 \mathrm{C}$ which recorded $68.17 \mathrm{~cm}, 978.43 \mathrm{~cm} 2,26.64 \%,(4.95,0.63,5.61) \%$ and 13.25 days respectively [5].

Calcium is very important element for the tulip bulbs to prevent stem topple, it contributes in cell wall structure as Calcium pectate important to growth the meristem tissues and cell wall solidification therefor it has less exposed to insect and diseases injury and reducing exposure to lie, it was necessary for building the primary cell wall [6].

Calcium increases the absorption of phosphorus, potassium and ammonium, stimulates photosynthesis [7]. N constituent of amino acids, proteins, amides nucleic acids, nucleotides[8], Wani et al. [9] were aimed to evaluate influence of calcium nitrate on plant growth of Asiatic lilies , they found that calcium nitrate improved significantly leaf area $(516.65 \mathrm{~cm} 2)$, plant height $(59.40 \mathrm{~cm})$ and number of leaves.plant-1 (80.94) at 105 days after planting. An experiment has been studied the influence of chelated calcium $(0,1,2)$ gm.L-1 as foliar spraying on Antirrium majus, showed that 1g.L-1 concentration improved plant height to $21 \mathrm{~cm}$, number of 
leaves 69.8, chlorophyll content $170.1 \mathrm{mg} . \mathrm{L}-1$, dry and wet weight for vegetative growth $(25.8,1.12) \mathrm{gm}$ and inflorescences number (23) [10]. Sahi[11] was spread calcium chloride at 1gm.L-1 concentration on Zinnia elegans significantly surpassed in increased the diameter of flower and stem. Adding different concentration of calcium chloride $(\mathrm{CaCl} 2.2 \mathrm{H} 2 \mathrm{O})$ and urea $(46 \% \mathrm{~N})$ on Lisianthus (Eustoma grandiflorum) led to early flowering (193 days) and chlorophyll increasing (393.61 mg/100gm) at Ca3N3 treatment (2310 mg.L-1 calcium chloride and 1005 mg.L-1 urea), enhanced Ca2N2 treatment (1540 mg.L-1) calcium chloride and 670 urea the stem height $(60.27 \mathrm{~cm})$, leaf area $(1508.66 \mathrm{~cm} 2)$ and the percentage of N,P,K,Ca and dry matter to $2.51,0.26,3.01$, 0.45 , and $19.42 \%$ respectively [12]. An experiment was executed to study the effect of three concentration of NPK (15-15-15) 0, 8 and 120 gm.m2 on Tulipa gesneriana, the last concentration enhanced most flowery growth properties [13] .

The lack of researches about tulip in middle of Iraq, animated us to study the influence of bio-fertilizer, Calcium nitrate and interaction between them on vegetative and flowery growth characteristics.

\section{Materials and methods}

This study carried out in lath house/Horticulture Dep./Baghdad Univ./Jaderia site for 2015-2016 year, Tulip bulbs (Orange cassing) variety, which purchased from Holland (De Ree company), sorted healthy bulbs and uniform size $(10-11) \mathrm{cm}$. half number of bulbs dipped in thick slurry of Azospirillm mbrasilense liquid fertilizer (6.2 X 108 cell bacteria/ml density) at half an hour that provide from Department of biocobtroldisease, biotechnology center, agricultural research office/ministry of science and technology, put them in shade place, then planted on 12/11/2015 in pots $(20 \mathrm{~cm})$ with 1 peatmoss :3 sand mixture, the physio, chemical and biological properties of the soil were assessed (Table1).

TABLE 1.Physio, Chemical and Biological Properties of The Soil

\begin{tabular}{lll}
\hline \hline Soil character & Value & Unit \\
\hline Ec & 0.5 & ds.m-1 \\
pH & 7,40 & - \\
Organic matter & 0,23 & $\%$ \\
Bacteria number & $3.8 \times 107$ & C.F.U / g.dry soil \\
N availability & 0.003 & $\%$ \\
P availability & 11.31 & mg.kg-1 \\
K availability & 97.21 & mg.kg-1 \\
\hline \hline
\end{tabular}

When the leaves has been full extension sprayed with Calcium nitrate $(0,627,1254) \mathrm{mg}$.L-1 on $7 / 3 / 2016$. The experiment designed as factorial with RCBD design, five replicates were used every one has five bulbs, compared totreatment means at least significant difference L.S.D at 5\% level.

\subsection{Studiedtraits:}

All vegetative and flowery characters has been measured at full opening stage: days to sprouting, leaves number, sprout number, leaves dry weight, leaf area, chlorophyll content, flower stem, flowering date, flower number, flower staying period on plant (flowering period), vase life, vase life for flower stored at 40Cfor 13 days, percentage of $\mathrm{N}, \mathrm{P}, \mathrm{K}, \mathrm{Ca}$ in leaves.

\section{Result and Discussion}

hg increased leaf dry weight and leaf area to $(0.25 \mathrm{~g})$ and $(158.17 \mathrm{~cm} 2)$ in plant treated withAzospirillum (A1), as well as the toppled stem percentage decreased to $16.67 \%$ at A1 treatment compared with control (46.89\%) (Table2). May be because it was provided balance nutrition for plant therefore leaf dry weight enhanced and less stem toppled recorded, fixed nitrogen and production of GA, IAA and cytokinin like substance [6], may be necessary for cell division and enlargement then increasing leaf area, that agree with Khalaf[5] he found surpassed bio-fertilizer treatment (Azospirillum brasilense + Glomus inatra dices + Glomus mossede) in increased leaf area and dry weight percentage of Dianthus caryophllus, and agree with Dubey and Misra[14] they observed increasing most parameters such as leaf area and dry weight when used dual 
inoculation (Azotobacter + PSB) on Gladiouls, dry matter weight in leaves was increased in treated plants may be due to the role of microorganisms in increasing nutrientsabsorption that important in carbohydrate [5] and proteins compounds synthesis and it were accumulation in plants [15].

We see the significant influence of calcium nitrate treatment on vegetative traits, $\mathrm{Ca} 2$ treatment recorded minimum days to sprouting (74.25 day), increasing leaves dry weight and leaf area to $0.27 \mathrm{~g}$ and $154.55 \mathrm{~cm} 2$ respectively at Ca1 treatment compared with others, and the stem toppled decreased to 30.00 may be because calcium nitrate consist of nitrogen which has been role in proteins formation, forms an integral part for chlorophyll molecule [16], nitrogen is an essential component of amino acid, nucleotides [17]. Spraying plant leaves with calcium which one of middle lamella component of the primary cell wall as calcium pectate substances, strengthen the cell wall and involve the cell membranes [18][19], that conferred plasticity of cell walls and cell enlargement lead to enhanced growth plants, that confirmed with [9] they found that calcium nitrate significantly increased leaf area (at 90 days after planting) to $530.99 \mathrm{~cm} 2$ while observed calcium nitrate didn't effect on leaves number and chlorophyll content (Table 2) .

In regarded to duel interaction between Azospirillum (A) and calcium nitrate $(\mathrm{Ca}), \mathrm{A} 0 \mathrm{Ca} 2$ recorded less days to sprouting (65.50 days), the $\mathrm{A} 1 \mathrm{Ca} 1$ and $\mathrm{A} 1 \mathrm{Ca} 2$ treatments surpassed in leaves dry weight and leaf area to $0.31 \mathrm{~g}$ and $176.87 \mathrm{~cm} 2$ respectively, while chlorophyll content increased $(98.22 \mathrm{mg} / 100 \mathrm{~g})$ at $\mathrm{A} 1 \mathrm{Ca} 0$ treatment, as well as $\mathrm{A} 1 \mathrm{Ca} 3$ treatment reduced stem toppled percentage to $0 \%$.

TABLE II. Effect of Bio-Fertilizer, Calcium nitrate and The Interaction Between

Them on The Vegetative Growth Traits.

\begin{tabular}{llllllll}
\hline \hline Treatment & $\begin{array}{l}\text { Days to } \\
\text { sprouting } \\
\text { (day) }\end{array}$ & $\begin{array}{l}\text { Leaves } \\
\text { number } \\
(\text { leaf })\end{array}$ & $\begin{array}{l}\text { Sprout } \\
\text { number } \\
\text { (sprout) }\end{array}$ & $\begin{array}{l}\text { Leaf dry } \\
\text { weight } \\
(\mathrm{g})\end{array}$ & $\begin{array}{l}\text { Leaf area } \\
(\mathrm{cm} 2)\end{array}$ & $\begin{array}{l}\text { Chlorophyll } \\
\text { content } \\
(\mathrm{mg} / 100 \mathrm{~g})\end{array}$ & $\begin{array}{l}\text { Toppled } \\
\text { stem }(\%)\end{array}$ \\
\hline & & & & & & & \\
A0 & 82.16 & 3 & 1.44 & 0.23 & 136.87 & 83.14 & 46.89 \\
A1 & 81.38 & 3.22 & 1.72 & 0.25 & 158.17 & 86,79 & 16.67 \\
L.S.D 0.05 & n.s & n.s & n.s & 0.0219 & 8.2872 & n.s & 2.874 \\
Ca0 & 93.08 & 3 & 2.33 & 0.23 & 140.80 & 90.43 & 35.00 \\
Ca1 & 78 & 3.16 & 1.75 & 0.27 & 154.55 & 79.16 & 30.00 \\
Ca2 & 74.25 & 3.16 & 0.66 & 0.23 & 147.21 & 85.32 & 30.33 \\
L.S.D 0.05 & 3.7151 & n.s & 1.1767 & 0.0268 & 10.15 & n.s & 3.520 \\
A0Ca0 & 91.50 & 3 & 2.66 & 0.24 & 159.79 & 82.64 & 40.00 \\
A0Ca1 & 89.50 & 3 & 1 & 0.23 & 133.28 & 71.97 & 40.00 \\
A0Ca2 & 65.50 & 3 & 0.66 & 0.22 & 117.65 & 94.82 & 60.67 \\
A1Ca0 & 94.66 & 3 & 2 & 0.22 & 121.81 & 98.22 & 30.00 \\
A1Ca1 & 66.5 & 3.33 & 2.5 & 0.31 & 175.87 & 86.35 & 20.00 \\
A1Ca2 & 83 & 3.33 & 0.66 & 0.24 & 176.87 & 75.82 & 0.00 \\
L.S.D 0.05 & 5.254 & n.s & 1.6641 & 0.0379 & 14.3540 & 16.8810 & 4.979 \\
\hline \hline
\end{tabular}

flowery traits showed in Table 3 such as flowering period and Vase life of stored flower at 40C for 13 days were reached to 6.44 and 3.33 days respectively at A0 treatment, while A treatment didn't significantly effect on the rest flowery traits, that didn't agree with Gupta et al. [20] they used bio-fertilizer like VAM, Azospirillum, PSB treatment on Carnation, increased plant height, vase life and recorded minimum days to flowering. Treatment which was under calcium nitrate $(\mathrm{Ca} 1)$ influence reached to exclusive flowery characteristics such as flower stem height $(21.65 \mathrm{~cm}), \mathrm{Ca} 2$ treatment increased flowers number and vase life that stored at $40 \mathrm{C}$ for 13 days to 1.33 flower and 3 days respectively, that agree with Wani et al. [9] they found increased plant height at calcium nitrate treatment.

The interaction between $\mathrm{A}$ and $\mathrm{Ca}$ on flowery traits significantly effect on flower stem height at A0Ca1 treatment $(26.63 \mathrm{~cm})$ but A0Ca2 treatment increased flowers number, flowering period and vase life of flowers stored at 40C to 1.66 flower, 6.66 days and 4 days respectively. 
TABLE III. Effect of Bio-Fertilizer, Calcium Nitrate and The Interaction Between Them on The Flowery Growth Traits.

\begin{tabular}{lllllll}
\hline \hline Treatment & $\begin{array}{l}\text { Flower } \\
\text { stem } \\
\text { height } \\
(\mathrm{cm})\end{array}$ & $\begin{array}{l}\text { Flowering date } \\
\text { (day) }\end{array}$ & $\begin{array}{l}\text { Flower } \\
\text { number } \\
\text { (flower) }\end{array}$ & $\begin{array}{l}\text { Flowering } \\
\text { period (day) }\end{array}$ & $\begin{array}{l}\text { Vase } \\
\text { life } \\
\text { (day) }\end{array}$ & $\begin{array}{l}\text { Vase life for } \\
\text { flower stored } \\
\text { at } 4^{0} \text { C } \\
\text { (day) }\end{array}$ \\
\hline A0 & 20.96 & 132.33 & 1.22 & 6.44 & 3.66 & 3.33 \\
A1 & 20.33 & 135.44 & 1 & 5.55 & 3.66 & 2.11 \\
L.S.D 0.05 & n.s & n.s & n.s & 0.8729 & n.s & 0.4193 \\
Ca0 & 20.91 & 131.61 & 1 & 6 & 3.5 & 2.83 \\
Ca1 & 21.65 & 135.5 & 1 & 5.66 & 4 & 2.33 \\
Ca2 & 19.37 & 135 & 1.33 & 6.33 & 3.5 & 3 \\
L.S.D 0.05 & 1.818 & n.s & 0.2965 & n.s & n.s & 0.5136 \\
A0Ca0 & 19.5 & 122.66 & 1 & 6.33 & 4 & 3.33 \\
A0Ca1 & 26.63 & 139.66 & 1 & 6.33 & 4 & 2.66 \\
A0Ca2 & 16.75 & 134.66 & 1.66 & 6.66 & 3 & 4 \\
A1Ca0 & 22.33 & 139.66 & 1 & 5.66 & 3 & 2.33 \\
A1Ca1 & 16.66 & 131.33 & 1 & 5 & 4 & 2 \\
A1Ca2 & 22 & 135.33 & 1 & 6 & 4 & 2 \\
L.S.D 0.05 & 2.5711 & n.s & 0.4193 & 1.5119 & n.s & 0.7263 \\
\hline \hline
\end{tabular}

We couldn't observed the effect of bio-fertilizer on $\mathrm{N}, \mathrm{P}, \mathrm{K}$, and $\mathrm{Ca} \%$ (Table 4), but Ca1 treatment effect significantly in increased $\mathrm{N}, \mathrm{P}, \mathrm{K} \%$ to $1.47,0.53$ and $1.55 \%$, while $\mathrm{A} 1 \mathrm{Ca} 1$ recorded highest value in $\mathrm{P}, \mathrm{K}, \mathrm{Ca} \%$ $(0.56,1.64,0.27 \%)$, but the highest $\mathrm{N} \%$ was at $\mathrm{A} 0 \mathrm{Ca} 0(1.53 \%)$.

TABLE IV. Effect of Bio-Fertilizer, Calcium Nitrate and The Interaction Between

Them on N,P,K,Ca Percentage in Leaves.

\begin{tabular}{lllll}
\hline \hline Treatment & $\mathrm{N} \%$ & $\mathrm{P} \%$ & $\mathrm{~K} \%$ & $\mathrm{Ca} \%$ \\
\hline $\mathrm{A} 0$ & 1.41 & 0.51 & 1.37 & 0.23 \\
$\mathrm{~A} 1$ & 1.41 & 0.47 & 1.48 & 0.22 \\
L.S.D 0.05 & n.s & n.s & n.s & n.s \\
$\mathrm{Ca} 0$ & 1.41 & 0.49 & 1.25 & 0.21 \\
$\mathrm{Ca} 1$ & 1.47 & 0.53 & 1.55 & 0.25 \\
$\mathrm{Ca} 2$ & 1.35 & 0.44 & 1.46 & 0.21 \\
L.S.D 0.05 & 0.0682 & 0.0484 & 0.2652 & $\mathrm{n} . \mathrm{s}$ \\
$\mathrm{A} 0 \mathrm{Ca} 0$ & 1.53 & 0.52 & 1.19 & 0.25 \\
$\mathrm{~A} 0 \mathrm{Ca} 1$ & 1.41 & 0.51 & 1.47 & 0.23 \\
A0Ca2 & 1.3 & 0.49 & 1.45 & 0.23 \\
A1Ca0 & 1.3 & 0.47 & 1.32 & 0.18 \\
A1Ca1 & 1.52 & 0.56 & 1.64 & 0.27 \\
A1Ca2 & 1.41 & 0.39 & 1.48 & 0.2 \\
L.S.D 0.05 & 0.0965 & 0.0685 & 0.3750 & 0.0738 \\
\hline \hline
\end{tabular}

\section{References}

[1] J.M. Van Tuyland M.G.M.VanCreij, "Flower breeding and Genetics," Netherlands,ch.23, pp. 623-641, 2006. https://doi.org/10.1007/978-1-4020-4428-1_24

[2] J.K.Vessey .(August 2003). Plant growth promoting rhizobaceria as biofertilizers,Plant and soil, 255(2).pp.571-586. https://doi.org/10.1023/A:1026037216893

[3] F.U.Khan; M.A.A.Siddique;,F.A.Khan and I.T.Nazk. 2009 "Effect of biofertilizer on growth, flower quality and bulb yield in tulip (Tulipagesneriana),"Indian J. of agric. scie. 79(4).pp.248-251.

[4] A. Ali;T.Mehmood;A.Bashir;S.RazaNajam-ud-din and A.Ahmad,( jan-mar.2014) Investigation of biofertilizers influence on vegetative growth, flower quality, bulb yield and nutrient uptake in Gladiolus (Gladiolus grandiflorus L.)international j.of plant, animal and environmental sciences. 4(1).pp.94-99.

[5] Z.A.Khalaf, "Effect of bio-inoculator and organic fertilizer in carnation flowers growth and storage," M.S. thesis,Dept.Hort.,college of Agric., Baghdad Univ.,Baghdad, Iraq,2013.

[6] N.S.Ali;H.S.Rahi and A.A.Shaker, Soil Fertility, 1st .ed.Darktbalmya,Baghdad.iraq,2014,ch.7,pp147-159.

[7] S.E.Feagley, and L.B.Fenn,(September1998).Using soluble calcium to stimulate plant growth. Agricultural communication, The Texas A\&M university system. 
[8] L.Taiz, and E.Zeiger, Plant Physiology, 4th ed. sinauer associates. Inc. Publisher Sunderland, Massachusetts,2006,ch.5,pp.73-93.

[9] M.A Wanhi, ;T.Nazki, : and A.Din.2015.Effect of split application of ammoniacal and nitrate sources of nitrogen on Lilium growth and yield, J. of plant stress physiology. 1(1).pp.7-12.

[10] S.Abdallateef.2015. Influence of chelated Calcium and growing media on the growth and flowering of Antirrhinum majus, The Iraqi J. of Agric, Sci.46 (5).PP.813-818.

[11] [B.G.Sahi.(June2009). Effect of cycocel spray and calcium chloride on the growth and flowering of zinnia elegans.J. DuhokUniv.12(1). pp.39-43.

[12] S.A. Abdullatif, "Physiological study for production and storage of Lisianthus(Eustoma grandiflorum)" Ph.D. dissertation,Dept.Hort.,college of Agric., Baghdad Univ.,Baghdad, Iraq, 2006.

[13] B.S.I.Bairam.2013.Effect of chemical fertilizers levels (NPK) on the growth and flowering of two variety of Tulip (Tulipa gesneriana)Diyala agric. sciences J, 5(2).PP.312-318.

[14] R.K. Dubey, and R.L. Misra. 2006.Study of chemical and bio-fertilizer on gladiolus.Prog. Hort, 38(2).pp.165-171.

[15] E.A. Hobbie.2006. Carbon allocation to ectomycorrhiza fungi correlates with total below ground allocation in culture studie's .Ecology. 87(3). PP. 563-569.\{C.F.Z.A.Khalaf, "Effect of bio-inoculator and organic fertilizer in carnation flowers growth and storage," M.S. thesis,Dept.Hort.,college of Agric., Baghdad Univ.,Baghdad, Iraq,2013\}.

[16] S.L. Tisdale, and W.L.Nelson,Soil Fertility and Fertilizers, 4th ed the Macmillan company. New York,1961,ch.3,pp.40-52

[17] P.H. Raven; R.F. Evert and S.E. Eichhorn,Biology of Plant, 4th ed. Worth publishers, Inc. New york.1986,ch.26,pp.517-540.

[18] F.H.Al- Sahaf, Farming Systems Without The Use of Soil, Dar Al-Hikma press-Baghdad Uni. Ministry of higher education and scientific research. Iraq, 1989,ch.1,pp.13-62.(in Arabic).

[19] A.V. Barker,and D.J. Pilbeam,Handbook of Plant Nutrition,CRC.press,2007,ch.5,pp.121-144.

[20] Y.C. Gupta;B.Suman;Y.D.Sharma;R.Thakur, and J.Ritu.2004. Effect of growing media and fertilization on growth and flowering of Carnation (Dianthus caryophyllus L.) Under protected condition, Natl. symp. Rec. Trends Future Strategies Orna. Hort. PP.77.Abstract. 